\title{
DiVERZITÁS ÉS INKLÚZIÓ A FELSŐOKTATÁSBAN ${ }^{+}$
}

\author{
VARGA ARANKA - VITÉZ KITTI* - ORSÓS ISTVÁN - \\ FODOR BÁLINT - HORVÁTH GERGELY
}

Pécsi Tudományegyetem Bölcsészettudományi Kar, Neveléstudományi Intézet

Tanulmányunk hazai és nemzetközi írásokra támaszkodva tisztázza az inklúzió és a diverzitás fogalomkörét. Vizsgáljuk, hogy miként vált a felsőoktatás jellemzőjévé a diverzitás, valamint az inkluzivitás fókuszba kerülése mögött meghúzódó további okokat és következményeket. Kérdőíves kutatásunk arra irányult, hogy a Pécsi Tudományegyetem diverz hallgatói köre (N:809) mennyire részese az egyetemi közösségi és tudományos életnek, mutatnak-e különbséget a társadalmi hátránnyal küzdők a bevonódásban. A z eredmények rámutattak, hogy a nagy egyetemi programokon a társadalmi hátrányban levők alulreprezentáltak, azonban a szakkollégiumok és egyéb mikroközösségek nagyobb mértékben képesek a személyes megszólításra, az inkluzív közeg biztosítására.

Kulcsszavakः inklúzió, diverzitás, felsőoktatás, inclusive excellence

Our study clarifies the concepts of inclusion and diversity based on domestic and international studies. We examine how diversity has become a feature of higher education, and the additional causes and consequences behind the focus of inclusivity. Our questionnaire study explored the extent to which the diverse group of students of the University of Pecs (N: 809) is involved in the university social and academic life, and whether those with social disadvantages show a difference in involvement. The results revealed that socially disadvantaged students are underrepresented in large university programmes, however, student colleges and other micro-communities are more able to address these students in a personal way and to provide an inclusive environment.

Keywords: inclusion, diversity, higher education, inclusive excellence

* Levelező szerző: Vitéz Kitti, 7623 Pécs, Mezőszél utca 3/C. E-mail: deli.kitti@pte.hu

+ A tanulmány a Pécsi Tudományegyetem - EFOP-3.4.3-16-2016-00005 „Korszerü egyetem a modern városban: Értékközpontúság, nyitottság és befogadó szemlélet egy 21. századi felsőoktatási modellben" projekt részeként létrehozott - Befogadó Egyetem Program keretében készült szakkollégisták, PhD. hallgatók és oktatók együttmúködésével. 


\section{Bevezetés}

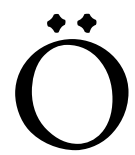

rvendetesnek mondható, hogy az inklúzió szemlélete és gyakorlata egyre szélesebb körben elterjedt, azonban mindez egyben a fogalom „erodálódását” is magával hozta. Tanulmányunkban arra vállalkozunk, hogy a témában született hazai és nemzetközi tudományos írásokra és saját kutatási eredményekre támaszkodva pontosítsuk az inklúzió fogalmának tartalmát, számba vegyük a fókuszba emelt csoportokat, és kiemelten foglalkozzunk a felsőoktatás befogadóvá válásának okaival, mikéntjével, előnyeivel.

\section{Az inklúzió megközelítései és gyakorlata}

\section{Inklúzió és diverzitás}

Az inklúzió egyre szélesebb körben, sokféle kontextusban és nem egységes tartalommal használatos fogalom. Jó néhány évtizeddel ezelött föként a fogyatékos gyermekek sikeres együttnevelését jelentette az UNESCO szakmapolitikai mozgalmának köszönhetően (UNESCO 1994, 2005). Az inkluzív pedagógia hatékony és eredményes működése révén és az „iskola mindenkinek” (school for all) reformnak köszönhetően kiterjedt más tanulói csoportok (szociálisan hátrányos helyzetűek, migráns hátterüek stb.) méltányos támogatásának megnevezésére is (Papp 2012; Hinz 2002). Az inklúzió oktatási vonatkozásának sokszínűségét jelzi, hogy a befogadás fókuszába emelt újabb tanulói csoportok mellett tartalmi elemekkel is bővült: integrálta például az USA-ból indult multikulturális pedagógia gyakorlatát, felváltotta a hazánkban használt „hátrányos helyzet pedagógiája” megközelítést, továbbá a felsőoktatási akadémiai kiválóság növelésének egyik eszközeként a diverz tanulási környezetet jelölte meg.

Politikai tartalommal, szociálpolitikai elvként az inklúzió szintén régóta használt fogalom, mely Európában a lisszaboni elvek (Presidency Conclusions 2000) között hangsúlyos helyet kapva terjedt el. A társadalmi befogadás (social inclusion) tágabb értelmü használata, a társadalompolitika esélyegyenlőtlenséget ellensúlyozó törekvéseit magába foglalva lépett túl az integrációs megközelítésen. Jellemző az is, hogy a különböző országok társadalom- és oktatáspolitikai dokumentumaiban az integráció/felzárkózás/ felzárkóztatás fogalmak sokszor az inklúzió szinonimájaként jelennek meg - új szemléleti és tartalmi elemekkel bővülve. Mindez kívánatossá teszi az egységes fogalomhasználatot, letisztult tartalommal.

Értelmezésünkben oktatási szempontból a kölcsönös befogadás (inclusion) szemléleti alapja az esélyegyenlőség (equality) biztosítása, mely oktatásszervezési szempontból az integrált tanulói környezetet jelenti. Ez egészül ki egyéni bánásmóddal és személyre szabott tartalommal, mely a méltányosságot (equity) érvényre juttatva segíti a befogadás fókuszában lévő különböző tanulók iskolai sikerességét (Varga 2015a). Az inkluzív iskolai környezet valamennyi diák sikerességének növelését úgy célozza, hogy bevonja, támogatja azokat, akik kizáródnának (exclusion) az oktatásból (UNESCO 2009a, 2009b).

A tanulók különbözősége (diversity) adódhat személyes, öröklött tulajdonságokból, és/vagy a társadalmi helyzet, illetve a kulturális környezet hatásaiból. A diverzitás egyéni szinten multidimenzionális, sokféle (kiemelkedő vagy hátrányt okozó) személyes 
tulajdonság alkot egységet (Dezső 2015), mely tulajdonságok fejlődését erősen befolyásolja a szociális és a kulturális környezet. Az egyén élethelyzetét döntően meghatározza, hogy jellemzői közül melyek kerülnek fókuszba. Ebben fontos szerepük van a társadalmi normáknak, melyek előnyös vagy hátrányos helyzetet teremtenek azzal, hogy hatásukra az egyénre jellemző sokféleség közül bizonyosak felértékelődnek, mások figyelmen kívül kerülnek, illetve elutasítást eredményeznek.

Napjainkban a tanulás intézményi környezetét vizsgálva a kutatók azt hangsúlyozzák, hogy az esélyegyenlőségi cselekvések az egyének és közösségek értékeit, szükségleteit felismerő és ahhoz igazodó környezetben tudnak maradéktalanul célt érni. Megközelítésünk szerint az inkluzív pedagógia szemléleti alapja, hogy minden személyre egyediségében tekint, személyes, szociális, kulturális jellemzői metszetében elhelyezve a diákot, alakít ki együttmüködő, támogató tanulási feltételeket. Az inkluzív környezetet és a sokféleség (diverzitás) sikeres kezelését az egyediségből következő szükségletekre való hatékony reagálással éri el. Nyitottságot tükröz, melyet az érintettek pozitív attitűdje, a sokszínűség értékelésének szemlélete jellemez. Fontos része a teret müködtetők (pedagógusok) szakmai felkészültsége, mely a diákok egyéni életútjának megértésében, személyre szabott és eredményes segítésében ölt testet. Közös cselekvés, partneri együttmüködés jellemzi, és a benne rejlő diverzitásra való sikeres reagálás alapfeltétele a folyamatos megújulás (Varga 2015a).

\section{Nemzetközi vizsgálatok és modellek}

$\mathrm{A} z$ inkluzivitás - annak ellenére, hogy a neveléstudomány történetében csak később megjelenő fogalom - hangsúlyos irányelv volt a történelemben, hiszen az egyetemek, universitasok befogadó központokként funkcionáltak (Kéri 2015). A tudás és a tudományok megosztása számos esetben felülírta a vallási és felekezeti különbségeket is - gondoljunk csak a középkorban muszlim tudósok által közvetített antik írók müveinek európai egyetemeken való feldolgozására. Ezek mellett megjelentek a színvonal növelésének biztosítására irányuló törekvések az esélyegyenlőség által, ahogy Kéri (2015) Mikonya Györgyöt idézi: „Egy-egy egyetem tudományos színvonala annál nagyobb volt, minél jobban igyekezett az egyenlőség eszményét érvényesíteni" (Kéri 2015: 121.). Kéri (2015) történeti áttekintésében többek közt megtalálhatók a származás és a nemzeti különbségek leküzdésére, a fogyatékosok befogadására és a hátrányos anyagi helyzet csökkentésére szolgáló ösztöndíjak kiterjesztésére való törekvések. Ezeken a példákon keresztül látható, hogy a felsőoktatási intézmények jelenlegi céljai részben a múltban gyökerező, befogadást célzó hagyományos célkitűzéseken alapulnak. Az inklúzió előtérbe kerülésében szerepet játszik a felsőoktatás expanziója is, mely olyan tanulói csoportok megjelenését eredményezte a 20. század második felében, melyek addig alulreprezentáltak voltak ezen az iskolafokon - legyen szó a nők, a fogyatékosok, az etnikai kisebbségek, az alacsony társadalmi-gazdasági helyzetüek vagy a migránsok csoportjáról (Casey 2016).

Az 1950-es évektől az amerikai polgárjogi mozgalom kiemelt fontosságú törekvése volt az afroamerikai kisebbség deszegregációja az oktatás minden szegmensében. Ekkor jelentek meg először a korszak publikációiban és bírósági ítéleteiben az „egyenlő oktatási lehetőség”, „egyenlő hozzáférés és méltányosság” kifejezések, melyek aztán irányt mutattak az 1960-as évek további törekvései számára a fekete kisebbség integrációja 
(később inklúziója) érdekében (Maples 2014: 30.). Ennek pozitív következménye, hogy a felsőoktatásban is megjelennek társadalmi-kulturális szempontból különböző diákok. A Diverse Learning Environment Model (DLE) (Hurtado et al. 2012) erre reflektálva kapcsolja össze a méltányos oktatási eredményeket befolyásoló, intézményen belüli (mikro) és az intézményre kívülről ható (makro) erőket. Kutatók vizsgálatai bizonyították, hogy a méltányosság érvényesülése együtt jár az oktatás minőségének javulásával, az akadémiai kiválóság növekedésével (Hurtado-Ruiz 2015). Ezen alapul az Inclusive Excellence (Milem-Chang-Antonio 2005; Williams-Joseph-Shederick 2005; Baumann et al. 2005) névvel fémjelzett, csaknem két évtizedes egyesült államokbeli felsőoktatásfejlesztési mozgalom.

A kétezres években az EU-ban is a felsőoktatás-kutatás részévé vált a diverzitás és inklúzió összefüggéseinek vizsgálata, a különböző tanulói csoportok jellemzőinek feltárása és eredményes támogatásuk módszereinek leírása (Cooper 2010, 2012; Varga 2015b).A 2019-ben kiadott, 159 felsőoktatási intézményt vizsgáló European Universities Association (EUA) kutatási összefoglaló (Claeys-Kulik -Jorgensen-Stöber 2019) rámutat arra, hogy a befogadás, a méltányosság és a sokszínűség növelése az intézmények jelentős $(88 \%)$ részében meghatározó célként szerepel Európában. A mentorálás, az akadálymentesített épületek, az anyagi támogatás mind elősegítik ezt a célt, amelyhez vezető három legfontosabb faktorként a felsőoktatási vezetők/döntéshozók elköteleződését (76\%), a célcsoportok direkt bevonását (48\%), az egész egyetemi közösség bevonódását (43\%), valamint a sokszínü tanulási környezet kialakítását (22\%) nevezték meg a válaszadók.

A nemzetközi irodalomban az inkluzív modellek hatékonyságát bizonyítják az azok alkalmazását vizsgáló kutatási eredmények. Az inkluzív környezet kialakítására az USA-ban az „inclusive excellence” fogalmát alkalmazzák (Milem-Chang-Antonio 2005), melynek eléréséhez szükséges a felsőoktatási környezet befogadásra irányuló tevékenységeinek kiterjesztése. Az egyetemi vezetések ugyanis a diverzitást központi értékként fogják fel a hallgatók boldogulása és az intézmények versenyképességének érdekében (O’Donnel et al. 2011; Danowitz-Tuitt 2011).

$\mathrm{A} z$ inkluzív fejlesztéseket górcső alá vevő munkák a befogadásban érintett csoportok szempontjából vizsgálják a beavatkozásokat, illetve feltárják az intézményi aspektusok szerinti szervezetfejlesztési stratégiákat. A diverzitás értelmezése a nemzetközi irodalomban eltér, a fogalmat a különböző országok kutatói az adott térség felsőoktatásának alulreprezentált csoportjainak sokszínűségére használják: így például az Egyesült Államokban jellemzően az afroamerikai és latin-amerikai (Harris-Lee 2019), illetve a fogyatékos hallgatók esetében (Lombardi-Murray-Dallas 2013; Burgstabler 2015), míg Kanadában (Guo-Jamal 2007) vagy Nyugat-Európában (Cooper 2010) a bevándorló családokból származó hallgatókra alkalmazzák. Sok szakirodalom diverzitást alkotó jellemzőként említi a különböző szexuális orientációt (Magnus-Lundin 2016; HarrisLee 2019), továbbá szinte mindenütt megjelenik a nők reprezentációja az adott intézményekben (Guo-Jamal 2007; Harris-Lee 2019).

A kutatók megállapítják, hogy a méltányosan támogatott hallgatói csoportok sikeres akadémiai tevékenységének támogatása mint egyetemi felelősség és cél, az adott felsőoktatási intézmény megítélését és a hallgatók mindenkori jóllétét egyaránt segíti, melyhez a beavatkozási stratégiák nélkülözhetetlenek (Bailey-Dynarski 2011; Myers 2016). A fejlesztési stratégiák egy része kiterjed az etnikai kisebbségekre (Musu-Gillette 
et al. 2016), akik értelemszerüen az eltérő kulturális örökségük miatt érintettek a befogadással kapcsolatos tevékenységekbe való bevonódásban, így a többségi társadalom és a kisebbség egymás kölcsönös megismerésével gazdagodhat. A fogyatékos hallgatók célcsoportját az inkluzív, méltányos szolgáltatások mellett az egyetemek a fizikai tér formálásával, az egyetemi épületek megközelíthetőségének át- és kialakításával segítik hozzá a gyakorlatban megvalósuló egyenlő hozzáférhetőséghez (Burgstabler 2015). A 21. században a különböző szexuális orientációjúak, szakirodalmakban szexuális kisebbségekként jelölt (sexual minority) inklúziója is előtérbe került, befogadásukat többek között az érzékenyítő programelemek segíthetik (Magnus-Lundin 2016). A felsőoktatásban alulreprezentált csoportokat, azaz például az alacsony szocioökonómiai státuszú hallgatókat az egyetemek hátránykompenzációs beavatkozásokkal támogatják, ami a lemorzsolódás csökkenését eredményezi (Sweeney 2013). Külön kiemelendő az, hogy a diverzitás elfogadása és értékként kezelése a nemzetközi szakirodalomban úgy kap kiemelt helyet, hogy az inkluzivitás növekedése nem kizárólag a támogatásra szoruló csoportok érvényesülését biztosítja, hanem a közös térben részt vevő valamennyi társadalmi csoport számára jövedelmező (Varga 2015a).

A kutatások alátámasztják az akadémiai kiválóság fejlődését az inkluzivitást elösegítő beavatkozások tükrében, ezért az inklúzióra való törekvés az egyetemi fejlesztési stratégia kardinális eleme (May-Bridger 2010; Solomon et al. 2017; Brusoni et al. 2014). A z inkluzív egyetemi környezet kialakítása eltérő szinteken valósul meg, harmonizálva a fent vázolt, különféle érintett csoportok megfelelő megszólításának és bevonásának leírásával. Az intézmények fejlesztésének stratégiáiban így helyet kapnak mind az oktatási tér fejlesztésére (Burgstabler 2015), az oktatói tevékenységek szélesítésére (MayBridger 2010), mind a hallgatókat célzó szolgáltatások kiterjesztésére (Burgstabler 2015) vonatkozó programelemek. Az inkluzív fejlesztés fenntarthatósága miatt folyamatos beavatkozásokra van szükség a további sikerek elérésének érdekében (Arató-Varga 2015; Nolan-Targett 2017).

\section{Magyarországi jellemzők és kezdeményezések}

A felsőoktatási expanzió kialakulásának okai között felfedezhető az 1960-as, 1970-es évekre tehető demográfiai robbanás, a növekvő iskolázási törekvés a szülők részéről, illetve a társadalompolitikai célként megfogalmazott iskoláztatási arányok növekedése (Coombs 1971, idézi Polónyi 2014). Szociológiai okok között szerepel a társadalmi osztályok újratermelése, mint az oktatás egyik feladata, valamint a státuszkonfliktuselmélet, mely szerint a különböző társadalmi csoportok célja a magasabb iskolázottság elérése. A 21. századi felsőoktatást jellemzi a diverzifikálás, mely a „hallgatók kiterjesztése új korosztályokra és új képzési formákra, részint a felsőoktatás kutatási, szolgáltatási tevékenységeinek kiszélesítése" (Polónyi 2014: 193.). Hives-Kozma (2014) tanulmánya rámutat, hogy az expanzió értelmezése komplex, így érdemes több szempontból is vizsgálni, akár a felsőoktatás tömegesedésének (hallgatói, keresleti oldal), akár a felsőoktatás bővülésének (intézményi, kínálati oldal) aspektusából. 1990-2005 között négyszeresére emelkedett a hazai felsőoktatásban tanulók száma, azonban a 2000-es évek közepére telítődni látszott a felsőoktatás. Ezt mutatja, hogy „2004-2013 között a felsőoktatásban tanuló hallgatók száma 24\%-kal (több mint 100 ezer fövel) csökkent" Magyarországon (Híves-Kozma 2014: 241.). A szerzőpáros szerint oktatáspolitikai 
kérdés az, hogy az expanzió folytatódhat-e, ugyanis szerintük a lemaradó társadalmi csoportok, vagy (ahogy ők nevezik) „a nem szokványos hallgatóság” - így például a hazai cigányság vagy a külföldi hallgatók csoportja - jelentheti a felsőoktatási expanzió tartalékát.

A Felsőoktatás szociális dimenziója címü, 2016-ban megjelent kiadvány részletes képet ad a hazai felsőoktatásban lévő hátrányos helyzetű csoportokról, tisztázza a jogszabályi hátteret, törekszik a felsőoktatásba való bekerülés, illetve a munkaerőpiaci kilépés lehetőségeit is bemutatni. A kötetben számba vett hátrányos helyzetben lévő csoportokba tartoznak a szociálisan hátrányos helyzetü, a fogyatékossággal élö, a kisgyermeket nevelő és a határon túli hallgatók. A cigány/roma hallgatók vonatkozásában nem áll rendelkezésre semmilyen adat a bekerülést illetően, így ez a csoport nem kapott helyet jelen felsorolásban (Fehérvári et al. 2016). Más kutatások rámutatnak, hogy legtöbb szociálisan hátrányos helyzetü diák olyan középfokú intézményben tanul, mely nem az érettségi megszerzésével zárul, így nem teljesíthető az EU célkitűzése sem, miszerint a felsőoktatásban olyan hátrányos helyzetű arányt kellene elérni, mint amekkora a társadalmon belüli arányuk (Hegedüs 2020). Ezt a tényt erősíti meg egy 2020-as vizsgálat (Proity 2020), mely szerint a hátrányos helyzet szabályozójának változása és a társadalompolitikai döntések azt eredményezték, hogy alig van hallgató, aki a felsőoktatási felvételi eljárás során kompenzációban részesülhetne társadalmi hátrányai miatt.

$\mathrm{A} z$ alábbi néhány példa a hazai, vidéki egyetemeket érintő tendenciákat, törekvéseket veszi számba. A Debreceni Egyetem (DE) a hallgatólétszámot tekintve 2015-ig az ország legnagyobb, 2015 óta a második legnagyobb egyeteme (Polónyi 2019). Ahogy Hives és Kozma hangsúlyozta (2014), a „nem szokványos hallgatóság” adhatja egyik bázisát a hazai felsőoktatásnak - erre láthatunk példát a Debreceni Egyetem esetében, ahol a hallgatóság 7/8-a a saját és a szomszédos megyékből kerül ki. A 2010 és 2016 között vizsgált „felvételi adatbázis alapján meghatározott 20 leghátrányosabb helyzetű kistérségből, a hátrányos helyzet $(\mathrm{HH})$ miatt kompenzációs pontban részesülő fiatalok negyedét a DE fogadja" (Polónyi 2019: 28.). Más vidéki egyetemek, például a Pécsi Tudományegyem (PTE) ezzel szemben kevésbé képes a $\mathrm{HH}$ hallgatók elérésére. Fontos kiemelni azt a Debreceni Egyetemen lezajlott kutatási projektet, mely 1295 hallgatót vizsgált a reziliencia szemszögéből a társadalmi háttér és a bemeneti eredmények mentén (Ceglédi 2018). A vizsgálat rámutatott, hogy a hallgató-oktató kapcsolat, a kortárskapcsolatok, a kutatásokba és az egyetemi életbe történő bevonódás mértéke jelentősen meghatározza a hallgató rezilienssé válását. Rayman és Varga (2015) is hangsúlyozzák, hogy a reziliens egyetemi hallgatók esetében több protektív faktort, támogató szereplöt lehet találni, ugyanakkor kortársaikhoz képest több hátráltató tényezővel kell szembenézniük a környezet inkluzivitásának hiánya miatt. Mindezek arra hívják fel a figyelmet, hogy a társadalmi egyenlőtlenségek a felsőoktatásban s azon túl is jelen vannak. A rezilienciakutatások azt is kiemelik, hogy azok a hallgatók, akik családjukból elsőként kerültek a felsőoktatásba, még inkább veszélyeztetettek a lemorzsolódással, mert hiába tekinthető reziliensnek addigi életútján egy hallgató, csak nehezen vagy egyáltalán nem tudja felvenni a versenyt azokkal, akik jobb családi háttérből érkeztek (Ceglédi 2018; Durst-Bereményi 2020). Éppen ezért van kiemelkedő jelentősége annak, hogy az iskolai pályafutás során hátránnyal haladókat minél fejlettebb inkluzív intézményi környezet vegye körül (Rayman-Varga 2015; Varga-Deli-Fodor 2019; Bereményi-Durst 2021). 
A PTE-n 2015-től zajlik felsőoktatási befogadás fókuszú kutatásfejlesztés (AratóVarga 2015), 2018-ban pedig létrejött a Befogadó Egyetem Program. Ez utóbbi keretében zajlott az a vizsgálat, mely a PTE összes karára kiterjedő kérdőíves adatfelvétellel és mélyinterjúkkal tárta fel a befogadást támogató programokat, illetve kereste az inklúzióval kapcsolatos hiányterületeket. A helyzetfeltáró kutatás legfőbb megállapítása, hogy három hallgatói csoport (külföldi, fogyatékos és társadalmi hátránnyal küzdő, köztük cigány/roma hallgatók) méltányos támogatása van jelen leginkább a PTE-n. Szervezeti oldalról láthatóvá vált, hogy a befogadást igénylő hallgatók egyéni és közösségi támogatása sokkal inkább jellemzi a vizsgált egyetemet, és kevésbé találhatók olyan beavatkozások, melyek a felsőoktatási környezet egészére vannak hatással (Varga-Deli-Fodor 2019).

E vizsgálat folytatásának tekinthető az a jelenleg is zajló kutatás, mely több aspektusból vizsgálja a PTE polgárait (hallgatók, oktatók, személyzet) a 2010-2020 közötti időszakban. A kutatás kiemelten foglalkozik a befogadás szempontjából fókuszban lévő hallgatói csoportokkal, és többféle vizsgálati módszerrel törekszik feltárni, hogy a sikeres hallgatókat milyen támogató feltételek segítették, valamint a sikertelen hallgatóknál milyen út vezetett a lemorzsolódáshoz. Mindez segíthet beazonosítani azokat a hiányterületeket, melyek fejlesztésével befogadóbbá tehető az egyetem.

\section{Kutatói kérdések és módszerek}

A z elözőekben leírtak szerint minél inkluzívabb egy egyetem, annál inkább meg tudja szólítani a hallgatóit, be tudja vonni a különböző közösségi, tudományos tevékenységekbe, ezzel képes az akadémiai kiválóságot növelni - függetlenül a hallgató szociokulturális hátterétől. Kutatásunk a Pécsi Tudományegyetem nappali tagozaton tanuló magyar diákjai körében zajlott, és arra kerestük a választ, hogy mi jellemzi a hallgatók részvételét az egyetemi életben. Mutatnak-e különbséget a bevonódásban a hátrányos helyzetü, cigány/roma egyetemisták? Kíváncsiak voltunk, hogy a megjelenés, illetve a távolmaradás mögött milyen okok húzódnak meg, és arra is, hogy az okok eltérnek-e a befogadás szempontjából kiemelt vizsgálati csoportunk válaszaiban? Kérdéseink egy része arra irányult, hogy a tehetséggondozást (akadémiai kiválóságot) célzó formális hallgatói együttműködés (szakkollégium) szerepet játszik-e a különböző hallgatók megszólításában. Kérdés volt az is, hogy van-e együttjárás a közösségi és kulturális programokon való részvétel és a hallgatói tudományos életben mutatott aktivitás között?

A kutatás lebonyolításához online kérdőívet használtunk, hozzáférés-alapú mintavétellel. A kérdőívet 2019 decemberében a Neptun rendszeren keresztül juttattuk el a vizsgált csoport valamennyi tagjához (N:11384, forrás: PTE adatbázis 2019), melyből 880 fö töltötte ki, és az adattisztítás után 809 válaszadó kérdőíve volt értékelhető. A kérdőív összesen 42 kérdésből állt, a többnyire zárt kérdések mellett - különösen az okokra vonatkozóan - nyitott kérdések is szerepeltek. A kérdőívek SPSS programmal történt elemzése a fenti kérdések mentén elsősorban a hátrányos helyzetű, illetve cigány/roma egyetemisták és a többségi hallgatók közötti különbségekre és hasonlóságokra fókuszált. 


\section{Eredmények}

\section{A mintáról}

$\mathrm{A} z$ eredmények validitása szempontjából fontos megemlíteni, hogy a vizsgálati minta 7,11\%-os aránya mellett torzítást okozhat, hogy vélhetően az önkéntes kitöltést az egyetem iránt elkötelezettebb (bevonódottabb) hallgatók vállalták. Úgy véljük, hogy ezzel együtt lehetőség van értékelhető választ kapni kérdéseinkre. A demográfiai adatok elemzése során vizsgáltuk a mintában szereplő cigány/roma és/vagy hátrányos helyzetű hallgatók arányát. Arra vonatkozóan nincsenek adatok, hogy a PTE-n összességében mekkora ezen hallgatók aránya, így országos adatokra és becslésekre támaszkodtunk a reprezentativitás megállapításakor. 2015 és 2018 között azok a felsőoktatásba felvételt nyert diákok, akik hátrányos vagy halmozottan hátrányos helyzetük jogcímén többlettpontban részesültek, az összes felvett jelentkező alig 1\%-át $(0,98-0,88 \%)$ teszik ki (Proity 2020). Ez csak bemeneti adat, nem számolva az esetleges lemorzsolódással. A Roma Szakkollégiumi Hálózat becslései alapján a cigány/roma hallgatók ennél alacsonyabb arányban vannak jelen az egyetemeken. A két csoport között szintén csak becsülni tudjuk az átfedést, így 1,5\% közöttinek vesszük a hátrányos helyzetű és/vagy cigány/roma diákok felsőoktatási reprezentációját.

$\mathrm{Az}$ 1. táblázatban látható kutatási mintánk (N:809) megoszlása: a hátrányos helyzetủ válaszadói csoportja ( $\mathrm{N}: 12)$, a cigány/roma válaszadók ( $\mathrm{N}: 14)$, valamint azok, akik mindkét kategóriába besorolták magukat (N:10). A számosság miatt nagyrészt egyben (N:36) tárgyaljuk a három csoportot, és az idetartozókat „Fókusz” elnevezéssel jelöljük. Külön csoportot alkotnak azok a válaszadók, akik az előző kategóriákba nem tartoznak, őket „Kontroll” (N:773) megnevezéssel kontrollcsoportnak tekintjük. A mintánk megoszlása (Fókusz 4,45\%, Kontroll 95,55\%) azt jelzi, hogy az országosra becsült felsőoktatási reprezentációnál háromszor többen kerültek a mintába a vizsgálatunk fókuszában lévő hallgatók, amit okozhat a kérdőív tematikája és a kutatócsoport ismeretségi köre is.

1. táblázat: A minta társadalmi háttér szerinti megoszlása (N:809)

\begin{tabular}{lrrrrrc}
\hline Mintába kerülés szempontjai & Fö & \multicolumn{1}{c}{$\%$} & Nő & Férfi & $\begin{array}{r}\text { Nő } \\
(\%)\end{array}$ & $\begin{array}{c}\text { Férfi } \\
(\%)\end{array}$ \\
\hline Fókuszcsoport összesen & $\mathbf{3 6}$ & $\mathbf{4 , 4 5}$ & $\mathbf{1 9}$ & $\mathbf{1 7}$ & $\mathbf{5 4 , 2 9}$ & $\mathbf{4 5 , 7 1}$ \\
Hátrányos helyzetű & 12 & 1,48 & 6 & 6 & 50,00 & 50,00 \\
Cigány/roma & 14 & 1,73 & 6 & 8 & 42,86 & 57,14 \\
Hátrányos helyzetű és cigány/roma & 10 & 1,24 & 7 & 3 & 70,00 & 30,00 \\
Kontrollcsoport & $\mathbf{7 7 3}$ & $\mathbf{9 5 , 5 5}$ & $\mathbf{5 5 1}$ & $\mathbf{2 2 2}$ & $\mathbf{7 1 , 2 8}$ & $\mathbf{2 8 , 7 2}$ \\
\hline Összesen & $\mathbf{8 0 9}$ & $\mathbf{1 0 0 , 0 0}$ & $\mathbf{5 7 0}$ & $\mathbf{2 3 9}$ & $\mathbf{7 0 , 4 6}$ & $\mathbf{2 9 , 5 4}$ \\
\hline
\end{tabular}

A Fókuszba tartozók szüleinek iskolai végzettsége várakozásunknak megfelelő: az összesen 72 szülő 42\%-a (19 anya, 11 apa) 8 általános iskolai osztályt végzett vagy az alatti végzettségü. A szülők több mint fele (2 szakmunkás, 2 érettségizett, 1 diplomás anya, továbbá 18 szakmunkás, 4 érettségizett, 3 diplomás apa) azonban az elindult 
mobilitásra utal. A Kontroll is rétegzett: 90 hallgató (11,64\%) szüleinek érettségi alatti a végzettsége, ezen belül $5 \%$ az, akinek apja és/vagy anyja csak 8 osztályt végzett. A csoport egynegyede (24,45\%) mindkét szülőjének, illetve az anyák 41,4\%-ának, míg az apák 34,7\%-ának van diplomája. A két csoport közötti társadalmi távolságot a 2. táblázat összegzően mutatja. Érdekesség, hogy a kérdőív kitöltői között a nők magasabb számban vannak jelen, miközben a PTE hallgatóinak a nemi megoszlása ezt nem indokolja (3. táblázat), a Fókusz nő/férfi megoszlása ezzel szemben alig tér el.

2. táblázat: Szülők végzettsége (\% - Fókusz N:72, Kontroll N:1546)

\begin{tabular}{|c|c|c|c|c|c|c|}
\hline \multirow{2}{*}{$\begin{array}{l}\text { Legmagasabb } \\
\text { végzettség }\end{array}$} & \multicolumn{2}{|c|}{ Anya } & \multicolumn{2}{|c|}{ Apa } & \multicolumn{2}{|c|}{ Anya és apa együtt } \\
\hline & $\begin{array}{c}\text { Fókusz } \\
(\%)\end{array}$ & $\begin{array}{c}\text { Kontroll } \\
(\%)\end{array}$ & $\begin{array}{c}\text { Fókusz } \\
(\%)\end{array}$ & $\begin{array}{c}\text { Kontroll } \\
(\%)\end{array}$ & $\begin{array}{c}\text { Fókusz } \\
(\%)\end{array}$ & $\begin{array}{c}\text { Kontroll } \\
(\%)\end{array}$ \\
\hline $\begin{array}{l}8 \text { általános, } \\
\text { szakmunkás }\end{array}$ & 86,11 & 17,46 & 55,56 & 27,81 & 70,83 & 22,64 \\
\hline érettségi, diploma & 13,89 & 82,54 & 44,44 & 72,19 & 29,17 & 77,36 \\
\hline
\end{tabular}

3. táblázat: Karok közötti megoszlás

\begin{tabular}{|c|c|c|c|c|c|c|c|c|c|c|c|}
\hline \multirow[t]{3}{*}{$\begin{array}{l}\text { PTE } \\
\text { karok }\end{array}$} & \multicolumn{4}{|c|}{$\begin{array}{c}\text { PTE magyar nappalis hallgatók } \\
\text { 2019/2020 I. félév }\end{array}$} & \multicolumn{7}{|c|}{ Kérdőívet kitöltők } \\
\hline & \multirow[b]{2}{*}{$\begin{array}{l}\text { Férfi } \\
(\text { fö) }\end{array}$} & \multirow[b]{2}{*}{$\begin{array}{l}\text { Nö } \\
\left(f_{o}^{\prime \prime}\right)\end{array}$} & \multicolumn{2}{|c|}{ Összesen } & \multicolumn{4}{|c|}{ Fókuszban lévő hallgatók (fö) } & \multirow[b]{2}{*}{ 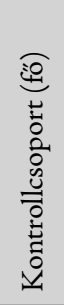 } & \multirow[b]{2}{*}{ 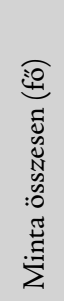 } & \multirow[b]{2}{*}{ 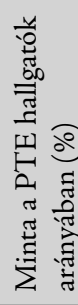 } \\
\hline & & & fö & $\%$ & 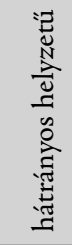 & 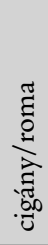 & 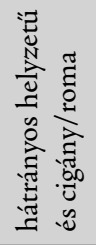 & 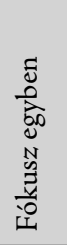 & & & \\
\hline AJK & 272 & 356 & 628 & 5,51 & 3 & 0 & 0 & 3 & 27 & 30 & 4,78 \\
\hline $\mathrm{AOK}$ & 558 & 885 & 1443 & 12,67 & 0 & 2 & 1 & 3 & 100 & 103 & 7,14 \\
\hline BTK & 651 & 1473 & 2124 & 18,65 & 5 & 7 & 4 & 16 & 199 & 215 & 10,12 \\
\hline ETK & 342 & 1664 & 2006 & 17,62 & 0 & 0 & 1 & 1 & 110 & 111 & 5,53 \\
\hline GYTK & 97 & 186 & 283 & 2,48 & 0 & 0 & 0 & 0 & 24 & 24 & 8,48 \\
\hline KPVK & 18 & 174 & 192 & 1,68 & 0 & 1 & 0 & 1 & 23 & 24 & 12,50 \\
\hline KTK & 591 & 918 & 1509 & 13,25 & 0 & 1 & 2 & 3 & 106 & 109 & 7,22 \\
\hline MIK & 934 & 330 & 1264 & 11,10 & 4 & 2 & 0 & 6 & 69 & 75 & 5,93 \\
\hline MK & 161 & 274 & 435 & 3,82 & 0 & 0 & 0 & 0 & 12 & 12 & 2,76 \\
\hline TTK & 959 & 541 & 1500 & 13,17 & 0 & 1 & 2 & 3 & 103 & 106 & 7,07 \\
\hline Össz. & 4583 & 6801 & 11384 & 100 & 12 & 14 & 10 & 36 & 773 & 809 & 7,11 \\
\hline
\end{tabular}


A PTE-s hallgatók kari megoszlását összevetve a kitöltők kari megoszlásával, az látható, hogy két kar esetén van megközelítő arány (ÁJK, MK), alulreprezentáltság jellemez különböző arányban hat kart. Két kar (GYTK és KPVKP) válaszadói felülreprezentáltak, amit az alacsony hallgatói létszám is valószínűsíthet. Összességében elmondhatjuk, hogy a kérdőíves felmérésünk nem tekinthető reprezentatívnak. Fontos megjegyezni, hogy a Fókuszba tartozók 44\%-a a Bölcsészettudományi Kar hallgatója.

Az egyetemen eltöltött évek szempontjából sem találtunk számottevő különbséget. A válaszadók átlagosan 2,68 éve az egyetem hallgatói, melynek átlaga a Fókuszon belül 3,07, illetve a Kontrollban 2,4 év. A szórás a Fókusz esetében 6 év, míg a Kontroll válaszadói között ez 7 év volt.

\section{Közösségi bevonódás és tudományos élet}

A közösségi és kulturális programokon való részvétel áttekintése azért fontos szempont, mert az inkluzivitás mérhető abban, hogy a különböző egyetemi programok mennyire tudják megszólítani a hallgatókat. A programok közül azokat tüntettük fel, melyek leginkább népszerűek a válaszadói körben, illetve amelyektől legnagyobb arányú a távolmaradás.

4, táblázat: Melyik eseményeken vettél részt?

\begin{tabular}{lcccccc}
\hline Esemény & $\begin{array}{c}\text { Összes } \\
\left(\mathrm{fö}^{\prime \prime}\right.\end{array}$ & $\begin{array}{c}\text { Összes } \\
(\%)\end{array}$ & $\begin{array}{c}\text { Fókusz } \\
\left(\mathrm{foó}^{\prime \prime}\right.\end{array}$ & $\begin{array}{c}\text { Kontroll } \\
\left(\mathrm{foó}^{\prime \prime}\right.\end{array}$ & $\begin{array}{c}\text { Fókusz } \\
(\%)\end{array}$ & $\begin{array}{c}\text { Kontroll } \\
(\%)\end{array}$ \\
\hline Egyik sem & 371 & 45,86 & 19 & 352 & 52,78 & 46,18 \\
Gólyabál & 294 & 36,34 & 3 & 291 & 8,33 & 37,65 \\
Szakest & 164 & 20,27 & 8 & 156 & 22,22 & 20,18 \\
Októberfeszt & 114 & 14,09 & 9 & 105 & 25,00 & 13,58 \\
Szakhét & 64 & 7,91 & 2 & 62 & 5,56 & 8,02 \\
\hline
\end{tabular}

A vizsgálatban összesen 371 fö, a válaszadók mintegy fele jelölte azt, hogy egyáltalán nem szokott részt venni az egyetem által szervezett eseményeken (4. táblázat). A távolmaradással kapcsolatos indokok a Fókusz és a Kontroll csoportnál nem különböznek: mindkét csoportban föképpen az idő- és pénzhiányra hivatkoztak, illetve az egyetem és a lakóhely közötti ingázás nehézségeit emelték ki. A Kontroll válaszadói ezen felül az információ hiányát jelölték meg, illetve az események kevésbé vonzóak számukra. A programokon részt vevők leggyakrabban a barátaik, csoporttársaik megjelenését és ritkábban az érdeklődési körüket sorolták fel indokként. Itt sincs eltérés a Fókusz és a Kontroll hallgatói véleményében, vagyis kiemelhető a kortárscsoport fontossága.

A legnépszerűbb program kimagaslóan a gólyabál volt, azonban szembetűnően alacsony a Fókusz reprezentációja ezen az eseményen. A gólyabál az egyetemi élet első nagy eseménye, fontos mérföldkő lehet az egyetem hallgatói életébe való bekapcsolódásában. A Fókuszba tartozók kiugróan alacsony arányú részvétele ezen a programon azt jelzi, hogy az egyetem megkezdésekor különösen fontos kiemelt figyelmet fordítani az egye- 
temi életet nem ismerő hallgatók megszólítására, támogatására. Érdekes látni, hogy a második helyen legtöbbet említett esemény a szakest volt, melyen $20 \%$ körül vett rész mindkét csoport. Vélhetően az egyetemi élet folyamatában (és nem a belépéskor), valamint egy kisebb, ismerősebb közösség rendezvénye már a Fókuszba tartozó hallgatók számára is vonzóbb. A harmadik helyen, az elnevezésében is „hétköznapibb” esemény (fesztivál) a Fókusz hallgatóit jóval nagyobb arányban vonzotta, valószínü, hogy ez ismertebb számukra.

A részvételi arány mellett sokatmondó információ, hogy a programokon részt vevők milyen élményekkel távoztak róluk. A kitöltők ötfokú skálán jelölték elégedettségüket, ahol a Fókusz hallgatói alacsonyabb értékeket adtak meg. Ha figyelembe vesszük, hogy a Fókusz hallgatói ritkábban és kevesebben vesznek részt közösségi, kulturális programokon, és ha el is mennek oda, akkor kevésbé érzik jól magukat, akkor érdemes átgondolni, hogy miként lehet ezeket a programokat vonzóbbá tenni számukra.

A hallgatói tudományos élet, a tehetséggondozás, illetve annak formalizált közössége, a szakkollégium szintén segítheti az egyetemi bevonódás növelését. Különösen igaz ez a Fókuszba tartozó hallgatókra, akik közül kevesebben végeznek tudományos tevékenységet, mint ahányan szakkollégisták, és a szakkollégisták (8 fö) közül is csak hárman végeznek tudományos kutatásokat. Ebből arra következtethetünk, hogy a szakkollégium számukra inkább támogató közösség, melyet megerősít, hogy többségük a Roma Szakkollégiumi Hálózat két szakkollégiumának (WHSz, PERSZ-E) tagjai, és néhányan több egyetemi szakkollégiumhoz is tartoznak. A Kontroll hallgatói közül kétszer annyian végeznek tudományos munkát, mint ahányan szakkollégisták, és a Kontroll szakkollégistáinak mintegy fele végez csak tudományos tevékenységet (5. táblázat). A Kontroll hallgatói inkább vállalkoznak a tudományos munkára formális (szakkollégiumi) segítség nélkül, amiből az is következik, hogy a Fókuszba tartozó hallgatók tudományos életbe való bekapcsolását kiemelten fontos szervezetileg is támogatni.

5. táblázat: Tudományos munka és szakkollégiumi tagság

\begin{tabular}{|c|c|c|c|c|c|c|}
\hline & $\begin{array}{l}\text { Összes } \\
\text { (fö) }\end{array}$ & $\begin{array}{l}\text { Összes } \\
(\%)\end{array}$ & $\begin{array}{l}\text { Fókusz } \\
\text { (fö) }\end{array}$ & $\begin{array}{c}\text { Fókusz } \\
(\%)\end{array}$ & $\begin{array}{l}\text { Kontroll } \\
\text { (fö) }\end{array}$ & $\begin{array}{l}\text { Kontroll } \\
(\%)\end{array}$ \\
\hline Szakkollégista & 78 & 9,64 & 8 & 22,22 & 70 & 9,06 \\
\hline Tudományos tevékenységet végez & 149 & 18,42 & 6 & 16,67 & 143 & 18,50 \\
\hline $\begin{array}{l}\text { Tudományos tevékenységet végez } \\
\text { és szakkollégista }\end{array}$ & 40 & 4,94 & 3 & 8,33 & 37 & 4,79 \\
\hline $\begin{array}{l}\text { Tudományos tevékenységet végez, } \\
\text { de nem szakkollégista }\end{array}$ & 109 & 13,47 & 3 & 8,33 & 106 & 13,71 \\
\hline $\begin{array}{l}\text { Szakkollégista, de nem végez } \\
\text { tudományos tevékenységet }\end{array}$ & 38 & 4,70 & 5 & 13,89 & 33 & 4,27 \\
\hline
\end{tabular}

A szakkollégista hallgatókra az is jellemző, hogy inkább résztvevői a közösségi és kulturális programoknak, ami bizonyítja, hogy összességében nagyobb a bevonódásuk az egyetemi életbe. A szakkollégiumok tehát a hallgatók életének számos aspektusát támogatják, így az inkluzív fejlesztési stratégiák egyik fontos területét adhatják. Megállapít- 
ható, hogy a nagy, összegyetemi programok önmagukban nem elegendőek valamennyi hallgató megszólítására, míg a kisebb közösségi tevékenységek, a mikrocsoportokhoz (pl. szakkollégiumokhoz, tanszékekhez) tartozás jobban segítheti a személyes megszólítást.

6. táblázat: Kontrollcsoport megoszlása a szülők végzettsége szerint

\begin{tabular}{|c|c|c|c|}
\hline & & Fő & $\%$ \\
\hline $\begin{array}{l}\text { Kontrollcso } \\
\text { végzettségü }\end{array}$ & orton belül legalább az egyik szülő érettségizett vagy magasabb & 683 & 88 \\
\hline Kontrollcso & orton belül az egyik szülőnek nincs érettségije & 90 & 12 \\
\hline \multirow{4}{*}{ Ezen belül } & anya csak 8 osztályt végzett & 23 & 3 \\
\hline & apa csak 8 osztályt végzett & 9 & 1 \\
\hline & mindkét szülő csak 8 osztályt végzett & 6 & 1 \\
\hline & egyik szülö csak 8 osztályt végzett & 20 & 3 \\
\hline
\end{tabular}

A kutatás során szembetűnő volt a Kontrollba tartozó hallgatói csoport (N:773) társadalmi rétegzettsége, így fontosnak tartottuk a Kontrollon belül azokat a diákokat külön is vizsgálni, akik szüleinek nincs érettségije (N:90), így mobilitási szempontból a Fókuszhoz hasonlóak (6. táblázat). A közösségi, kulturális programokon ezen hallgatók több mint fele $(52,2 \%)$ egyáltalán nem vesz részt, mely a Fókuszhoz tartozókkal megegyezö arányú. A közösségi programoktól való távolmaradásuk okaként mindkét csoport válaszadói közül legtöbben az időhiányra, a távoli lakóhelyre és a munkára hivatkoznak, de volt, akinek „nem volt kivel mennem” volt a válasza. A szakkollégiumok még a Kontroll csoport átlagánál is alacsonyabb arányban $(8,8 \%)$ képesek megszólítani ezt a csoportot. Tudományos tevékenységet $14,4 \%$-uk végez, ami szintén alatta van mindkét vizsgált csoportnak. Azon kevesek, akik bekapcsolódtak a szakkollégiumi közösségbe és/vagy tudományos tevékenységekbe, a Kontrollhoz közelítő arányban kevésbé kutatnak önállóan és inkább a közösségi rész hangsúlyos náluk. Érdemes még az egyik egyetemi méltányos támogatásba való bevonódást (mentorprogram) is megvizsgálni. Látható (7. táblázat), hogy a vállaltan hátrányos helyzetűek szinte egyötödét, míg a hasonló támogatásra szoruló, alacsony iskolázottságú szülői környezetből érkezők egyhatodát éri el ez a program.

7. táblázat: Mentorprogramban kapott támogatás megoszlása a különböző vizsgált csoportok között

Mentorprogramban támogatást kapott

Fókuszcsoport (N:36)

Kontrollcsoport (N: 773)

Kontrollcsoporton belül az érettségi és afeletti szülőkkel rendelkező hallgatók ( N: 48) 48

Kontrollcsoporton belül az érettségi nélküli szülőkkel rendelkező hallgatók (N: 90)
Fö $\%$

$7 \quad 19,44$

86

11,13

7,03

13 
A Kontrollcsoport tehát számos olyan szempontból is diverznek tekinthető, mely befolyásolja a hallgatók bevonódását az egyetemi életbe. Az egyetem hallgatói összetétele a vizsgált szempontokon felül is olyan diverzitást mutat, mely a jelenleg elérhető támogató szolgáltatások nagymértékű kibővítését és újragondolását szükségszerüsíti. Mindezek továbbá arra irányítják a figyelmet, hogy a Fókuszban lévő - hátrányaikat jelölő - csoport mellett még van egy jelentős számú hallgatói csoport, akik méltányos támogatásra szorulnak, de őket képes a legkevésbé megszólítani az egyetem akár közösségi programjaival, akár a tudományos közösségekkel.

\section{Összegzés}

A vizsgálat során fény derült arra, hogy a nagy egyetemi programok csak egy részét képesek megszólítani a hallgatóknak, kiváltképp a hátrányban lévőknek. Fontos átgondolni, hogy milyen módon érhető el már a kezdetektől a nagyobb mértékü bevonódás, ezzel segítve az erősebb kötődést, az egyetemi polgárrá válást. Ebben szerepet játszhatnak a kisebb szervezeti egységek (pl. tanszékek), melyek a hallgatóik számára kínált közösségfejlesztő programjaik fejlesztésével lehetőséget biztosíthatnak a személyesség növelésére, a differenciált támogatásra. Szintén fontos kisközösségek a szakkollégiumok, melyek megerősítése azért is indokolt, mivel láthatóan egyidejűleg nyújtják a támogató kortársközösséget és az akadémiai kiválóság növelését segítő tehetséggondozást, és így a lemorzsolódás megelőzéséhez is hozzájárulhatnak. A személyes kapcsolat, melyet az összegyetemi programokkal szemben a szakkollégium lehetővé tesz, olyan jellegü figyelmet és támogatást eredményez, melyre a társadalmi mobilitás útjára lépett hallgatóknak feltétlenül szükségük van az egyetemi évek alatt.

A vizsgálat fontos hozadéka, hogy a hallgatói kör diverzitása pontosodott, és láthatóvá vált, hogy az egyetemen nagy számosággal jelen vannak hátrányos helyzetüként nem számon tartott hallgatók is. Számukra is elengedhetetlen a méltányos támogatás biztosítása, így megszólításuk, bevonásuk kiemelten fontos a sikeres előrehaladásuk érdekében. A vizsgálat arra is felhívja a figyelmet, hogy nem elegendő az intézményfejlesztési stratégia részévé tenni az inkluzív programok fejlesztését. A méltányos szolgáltatásoknak transzparenssé, vonzóvá, személyessé kell válniuk ahhoz, hogy a befogadás célcsoportjait megfelelően elérhessék. Csakis ezzel ellensúlyozható, hogy a programoktól való távolmaradás egyik oka, a „szégyellem a szegénységemet” jelensége. A hallgatói kör vizsgálata során feltárt diverzitás, valamint az intézményi rendszer és környezet számos hiányzó válaszlépése és felkészületlensége mélyebb kutatásokat indokol a hátránykompenzációs beavatkozások és az inkluzív szemlélet kiterjesztésének és megerősítésének érdekében.

\section{IRODALOM}

Arató F. \& Varga A. (2015, ed.) Inclusive University: How to Increase Academic Excellence Focusing on the Aspects of Inclusion. University of Pécs, Faculty of Humanities, Institute of Education, Pécs. Autonomy and Responsibility Study Volumes IV. http:// kompetenspedagogus.hu/sites/default/files/arato-f-varga-a-inclusive-university-univpecs-2015.pdf [Letöltve: 2020. 07. 25.] 
Bailey, M. \& Dynarski, S. (2011) Gains and Gaps: Changing Inequality in U.S. College Entry and Completion. Cambridge, National Bureau of Economic Research.

Bauman, G., Bustillos, L., Bensimon, E., Brown, Ch. \& Bartee, R. (2005) Achieving Equitable Educational Outcomes with All Students: The Institution's Roles and Responsibilities, Association of American Colleges and Universities. Washington (DC) USA.

Bereményi Á. \& Durst J. (2021, előkészületben) Meaning Making and Resilience among Academically High-Achieving Roma Women. Szociológiai Szemle.

Brusoni, M., Damian, R., Sauri, J. G. \& Jackson, S. (2014) The Concept of Excellence in Higher Education. European Association for Quality Assurance in Higher Education AISBL. Brussels.

Burgstahler, S. (2015) Universal Design of Higher Education: From Principles to Practice. Second edition. Boston, Harvard Education Press.

Casey, L. (2016) The Casey Review: A Review into Opportunity and Integration. London, Department for Communities and Local Government. https://assets.publishing.service. gov.uk/government/uploads/system/uploads/attachment_data/file/575973/The_Casey_ Review_Report.pdf [Letöltve: 2020. 07. 20.]

Ceglédi T. (2018) Ugródeszkán. Reziliencia és társadalmi egyenlötlenségek a felsöoktatásban. Oktatáskutatók Könyvtára 4. Cherd Hungary.

Claeys-Kulik, A., L. Jorgensen, T. E. \& Ströber, H. (2019) Diversity, Equity and Inclusion in European Higher Education Institutions. Results from the INVITED project. European University Association asbl. Brussels (Belgium).

Соомвs, P. H. (1971) Az oktatás világválsága. Rendszerelemzés. Budapest, Tankönyvkiadó.

Cooper, M. (2010, ed.) Changing the Culture of the Campus: Towards an Inclusive Higher Education - Ten Years on. London, European Access Network.

Cooper, M. (2012, ed.) Student Diversity in Higher Education: Conflicting Realities - Tensions affecting policy and action to widen access and participation. European Access Network, London.

Danowitz, M. A. \& Tuit t, F. (2011) Enacting Inclusivity through Engaged Pedagogy: A Higher Education Perspective. Equity E Excellence in Education, Vol. 44. No. 1. pp. 40-56.

Dezső R. (2015) Plurális intelligencia-koncepciók, tanulásközpontú pedagógiai megközelítések és az inkluzivitás összefüggései. In: Arató F. \& VArgA A. (eds) Befogadó Egyetem. Az akadémiai kiválóság fejlesztése az inklúzió szempontjainak érvényesitésével. Autonómia és Felelősség Tanulmánykötetek III. Pécs, Pécsi Tudományegyetem Bölcsészettudományi Kar, Neveléstudományi intézet. pp. 75-88.

Durst J. \& Bereményi Á. (2020, előkészületben) “I Felt I Arrived Home”: The Minority Trajectory of Mobility for First-In-Family Hungarian Roma Graduates. In: M. M. Mendes \& S. O. Toma (eds) Social and Economic vulnerability of Roma People. Berlin, Springer.

Fehérvári A., Misley H., Széll K., Szemerszki M. \& Veroszta Zs. (2016) A felsőoktatás szociális dimenziója. Hátrányos helyzetü csoportok bozzáférése és részvétele a felsőoktatásban cimü kutatás. Budapest, Tempus Közalapítvány.

Guo, S. \& Jamal, Z. (2007) Nurturing Cultural Diversity in Higher Education: A Critical Review of Selected Models. Canadian Journal of Higher Education, Vol. 37. No. 2. pp. 27-49.

Harris, T. N. \& Lee, C. N. (2019) Advocate-Mentoring: A Communicative Response to Diversity in Higher Education. Communication Education, Vol. 68. No. 1. pp. 103-113. 
Hegedưs R. (2020) Kompetenciák-Hátrányok-Térségek. Avagy honnan s hogyan jutnak el a hátrányos helyzetűek a felsőoktatásba? (Kézirat.)

Hinz, A. (2002) Von der Integration zur Inklusion - terminologisches Spiel oder konzeptionelle Weiterentwicklung. Zeitschrift für Heilpädagogik, Vol. 53. No. 9. pp. 354-361.

Híves T. \& Kozma T. (2014) Az expanzió vége? Educatio, Vol. 23. No. 2. pp. 239-252.

Hurtado, S., Alvarez, C. L., Guillermo, W. Ch., Cuellar, M. \& Arellano, L. (2012) A Model for Diverse Learning Environments the Scholarship on Creating and Assessing Conditions for Student Success. In: J. C. Smart \& M. B. Paulsen (eds) Higher Education: Handbook of Theory and Research, Higher Education: Handbook of Theory and Research 27. Springer Science and Business Media B.V. pp. 41-122.

Hurtado, S. \& Ruiz, A. A. (2015) Thinking about Race: The Salience of Racial Identity at Two- and Four-Year Colleges and the Climate for Diversity. Journal of Higher Education, Vol. 86. No. 1. pp. 127-155.

Kéri K. (2015) Befogadás és/vagy kirekesztés a régi egyetemeken. In: Arató F. \& VARGA A. (eds) Befogadó Egyetem. megj. helye és kiadója érvényesitésével. pp. 219-229.

Lombardi, A., Murray, C. \& Dallas, B. (2013) University Faculty Attitudes Toward Disability and Inclusive Instruction: Comparing Two Institutions. Journal of Postsecondary Education and Disability, Vol. 26. No. 3. pp. 221-232.

Magnus, C. D. \& Lundin, M. (2016) Challenging Norms: University Students' Views on Heteronormativity as a Matter of Diversity and Inclusion in Initial Teacher Education. International Journal of Educational Research, Vol. 79. pp. 76-85.

Maples, R. (2014) The Legacy of Desegregation: The Struggle for Equality in Higher Education. Palgrave-MacMillan.

May, H. \& Bridger, K. (2010) Developing and Embedding Inclusive Policy and Practice in Higher Education. York, The Higher Education Academy.

Milem, J., Chang, M. \& Antonio, A. (2005) Making Diversity Work: A Researched Based Perspective. Washington (DC), Association of American Colleges and Universities.

Musu-Gillette, L., Robinson, J., McFarland, J., KewalRamani, A., Zhang, A. \& Wilkinson-Flicker, S. (2016) Status and Trends in the Education of Racial and Ethnic Groups 2016 (NCES 2016-007). Washington (DC) U.S. Department of Education, National Center for Education Statistics.

Myers, B. (2016) The Flagship Diversity Divide. The Chronicle of Higher Education.

Nolan, J. \& Targett, N. (2017) Developing and Sustaining Inclusive Excellence and a Safe, Healthy, Equitable Campus Community at UNH. Interim Report Presidential Task Force on Campus Climate. New Hempshire.

O’Donnel, K., Hecsh, J., Underwood, T., Loker, W., Trecher, S. A., David, D., White, A. (2011) Putting High-Impact Practices and Inclusive Excellence at the Center of GE Reform: Lessons from the California State University LEAP Initiative. Peer Review, Vol. 13, No. 2. (Spring) pp. 22-25.

PAPp G. (2012) Az integráció, inklúzió fogalmak tartalmi elemzése gyógypedagógiai megközelítésben nemzetközi és magyar színtéren. Gyógypedagógiai Szemle, Vol. 40. Nos 4-5. pp. 295-304.

Polónyi I. (2014) Régi, új felsőoktatási expanzió. Educatio, Vol. 1. pp. 1-21.

Polóny I. (2019) Egyetemek és régiójuk - különös tekintettel a Debreceni Egyetemre. Debreceni Szemle, Vol. 27. No. 1.pp. 23-24.

Presidency Conclusions (2000) Presidency Conclusions - Lisbon European Council, 23 24 March 2000. http://www.europarl.europa.eu/summits/lis1_en.htm [Letöltve: 2020. 08. 15.] 
Proity P. (2020) Inklúzió a felsőoktatásban. Hátrányos és halmozottan hátrányos helyzetü jelentkezök a felsőoktatási felvételi eljárásban. Szakdolgozat. PTE BTK.

PTE adatbázis (2019)

Rayman J. \& Varga A. (2015) Reziliencia és inklúzió. Romológia, Vol. 3. No. 10. pp.1224.

Solomon, A., Rollins C., Brown, L. D. \& Wright, H. L. (2017) Data-Driven Action Plans for Student Success and Inclusive Excellence. Washington, Association of American Colleges and Universities.

Sweeney, K. (2013) Inclusive Excellence and Underrepresentation of Students of Color in Study Abroad. Interdisciplinary Journal of Study Abroad, Vol. 23. pp. 1-21.

UNESCO (1994) Salamanca Statement and Framework for Action on Special Needs Education. Salamanca, 7-10 June 1994.

UNESCO (2005) Guidelines for Inclusion: Ensuring Access to Education for All. Paris, UNESCO.

UNESCO (2009a) Policy Guidelines on Inclusion in Education. Paris, United Nations Educational, Scientific and Cultural Organization.

UNESCO (2009b) Defining an Inclusive Education Agenda: Reflections around the 48th Session of International Conference on Education. Geneva, UNESCO IBE.

VArga A. (2015a) Hátrányos helyzet és iskolarendszer. In: Kozma T., KIss V. Á., JANCsÁK Cs. \& Kéri K. (eds) Tanárképzés és oktatáskutatás. Debrecen, HERA. pp. 621-633.

VARga A. (2015b, ed.) PRÓBATÉTEL - A pécsi roma szakkollégiumi program értékelése. Pécs, PTE. https://wlislocki.pte.hu/sites/wlislocki.pte.hu/files/oldal_mo/00_whsz_ hun_beliv_print.pdf [Letöltve: 2020. 08. 15.]

Varga A., Deli K. \& Fodor B. (2019) A felsőoktatás befogadóvá válásának szemléleti kerete és gyakorlati megvalósítása a Pécsi Tudományegyetemen. Educatio, Vol. 28. No. 4. pp. 755-766.

Williams, D. A., Joseph, B. B. \& Shederick, A. Mc. (2005) Toward a Model of Inclusive Excellence and Change in Postsecondary Institutions. Washington (DC), Association of American Colleges and Universities.

A cikk a Creative Commons Attribution 4.0 International License (https://creativecommons.org/licenses/ by/4.0/) feltételei szerint publikált Open Access közlemény, melynek szellemében a cikk bármilyen médiumban szabadon felhasználható, megosztható és újraközölhető, feltéve, hogy az eredeti szerző és a közlés helye, illetve a CC License linkje és az esetlegesen végrehajtott módosítások feltüntetésre kerülnek. (SID_1) 